\title{
POLINGUA
}

Scientific Journal of Linguistics, Literature and Language Education

\section{Mandarin Language Students Illocutionary Acts in Japanese Language Learning at the University of Sumatera Utara}

\author{
Taulia $^{1}$, Laraiba Nasution ${ }^{2}$ \\ ${ }^{12}$ Japanese Department, Faculty of Language and Communication, Universitas Harapan Medan, Jl. Imam Bonjol No.35, Medan, Indonesia \\ E-mail: taulianasrun@gmail.com,nastilaraiba@gmail.com
}

\begin{abstract}
Speech acts play an essential role in language learning as an aspect that can improve a learner's ability to speak orally. In this research, illocutionary speech-acts were described in the Japanese language learning process for students of the Mandarin Language Department, Faculty of Cultural Sciences, University of Sumatera Utara. This research is qualitative. The data are speech acts in the lecture process in class, especially in the discussion. The data sources were 40 fourth-semester students of the Mandarin Language Department. The theory used was the Searle speech act theory. Data collection techniques were carried out through observation, recording, and note-taking techniques. Data analysis techniques were carried out applying Miles \& Huberman's opinion by condensing data through transcription of recorded data into written form, identifying forms, speech act functions, data presentation, and concluding. As a result, there were forms of illocutionary speech acts, namely directive, expressive, and declarative. Furthermore, the purpose used in class was in directive speech acts which were to order, ask, invite (engage). In other words, in expressive speech-act was praising, and in declarative speech-act was prohibiting. In conclusion, Japanese speech acts in Japanese class occured between lecturers and students and only consisted of several types of speech acts due to students' limited mastery of Japanese.
\end{abstract}

Keywords—Illocutionary Speech acts;Japanese; Speech act

Manuscript Received16 Jan.2021; Revised 15 Mar. 2021;Accepted 18 Mar.2021

\section{INTRODUCTION}

When communicating and interacting with the environment, humans are never separated from the use of spoken language. The oral language spoken by humans uses language as an action; this is called a speech act.

The speech act is an important part of communicating because understanding the meaning and meaning of the speech partner's speech is the key to good communication. For this reason, humans not only understand what the speaker has said but also the context used in the utterance. This kind of activity is related to speech acts, namely speech accompanied by movements, postures, and certain expressions.

In language learning, speech acts play an important role in learning interactions to improve learners' ability to speak orally, for example, in learning Japanese in college or University. Students who are mostly new to Japanese and learning Japanese will certainly experience limited vocabulary and sentence patterns. However, in classroom learning, students must use Japanese to communicate with lecturers and fellow students. This will make speech acts very instrumental in students' communication in the learning process.

The phenomenon of speech acts in this class allows students to perform illocutionary speech acts. The illocutionary speech act is a context of speech that serves to inform something and functions as an action used to do something (Nirmala, 2015, p. 142).

Initially, pragmatic research is a field that is considered insignificant in linguistics and is even considered a science outside of linguistic research. However, after the emergence of Austin (1962), Searle (1983), and Grice (2004), linguists began to incorporate pragmatics into grammatical theory, especially after the development of speech act theory 'speech act', sociolinguistics, psycholinguistics, and cognitive science in general. It was due to their awareness that learning a language was not only in terms of linguistics but also the influence of language on society.

Leech (1993) says that pragmatics can be useful to explain how an expression has meaning in a situation with its emphasis on analysis of politeness. Pragmatics differs from the grammar in determining the basis for purpose and judgment. 
The advantage obtained from studying pragmatics is stated by Yule (2006) that one can say what other people mean, their assumptions, their goals, and various actions (such as begging) while speaking. Pragmatics is related to studying the speaker's meaning (writer)'s means of communication and interpreted by the speaker (reader). Therefore, it can be said that pragmatics is the study of the meanings spoken, the meaning of the context, and how to get more meaning from what is said.

Speech acts in Japanese are called gengokoui (言語行為). The speech act is one of the studies in the field of pragmatics, as revealed by Koizumi (2001, p. 81):

言語行為の研究は、語用論の領域の研究として取 り扱っている。

Gengokoui no kenkyuu ha, goyouron no ryouiki no kenkyuu to shite toriatsukatte iru.

A study of speech acts is part of the research field of pragmatics.

Speech acts, which are part of pragmatic studies, were first introduced by Charles Morris in 1938 and then developed by Austin (1962). This theory introduces the concept of using language as an action, in the sense that speech functions not only to convey information, but there is an act of "doing something" in a speech. Austin distinguishes three types of speech acts, namely (1) locutionary act, (2) illocutionary act, and (3) perlocutionary act.

Locutionary act is the act of 'saying something,' which is saying something with the meaning of the word, "like I'm hungry." 'I' is a singular first-person, and 'hungry' refers to an empty stomach. The Illocutionary act is the act of 'doing something.' In that action, there is a purpose and function of the utterance. Taken from the example, hungry is meant to ask for rice. Perlocutionary acts refer to the result a speaker produces by saying something. The focus is more on the narrator's self. Therefore, it can be said that the implications of locational actions towards speakers are called perlocutionary act actions, and these implications can make speakers angry, happy, sympathetic, and so on.

Then the Speech Acts theory was emphasized by Searle explains that what is included in illocutionary acts are verbs that show the meaning of orders, beg, apologize, etc (Searle, 1983, p. 23).

The act of illocution in Japanese is called hatsuwanaikoui (発話内行為). The illocutionary act has the meaning contained in speech, namely trying to influence the interlocutor by doing something about the speech. Examples of illocutionary verbs are the promise, order, ask, threaten, and so on.

Searle in Rasa et al. (2019, p. 23) classifies illocutionary acts into five: Assertive, Directive, Commissive, Expressive, and Declarative.

\section{A. Assertive}

In Japanese, assertive is called dangenteki (断言 的). Assertive acts are a form of speech that binds the speaker to the proposition's truth expressed in the speech itself. The forms of assertive speech are stating, suggesting, boasting, complaining, and claiming. According to Rustono (1999, p. 40) assertive speech acts are speech acts that bind the speaker to the truth of what is being said. In this speech acts, speakers included are utterances stating, demanding, acknowledging, reporting, showing, mentioning, giving, testimony, speculating, etc. The same thing is expressed by Koizumi (2001, p. 336),

話し手が、ある命題を真実として述べる。(陳述、主 張など)

Hanashite ga, aru meidai wo shinjitsu to shitte noberu (chinjutsu, shuchounado),,

Speakers express certain propositions based on truth (statements, opinions, and so on)

Assertive act examples in Japanese:

雪が降っている（と伝える）

Yuki ga futteiru (to tsutaeru),

Snow is falling (convey) ${ }^{\text {ee }}$ (Koizumi, 1993, p. 336)

The speech is an assertive speech act because it binds the speaker to the truth of the speech's contents. The speaker is responsible for the information that has been conveyed the truth that he has spoken. The truth of this speech is obtained from the fact that it is according to the snowfall phenomenon. Thus, the speech contains the truth with the appropriate conditions.

\section{B. Directive}

In Japanese, the directive is called shijiteki (指示 的). A directive speech act is a form of speech intended by the speaker to make an impact so that the speech partner performs the actions he wants. The form of directive speech is ordering, commanding, requesting, advising, and recommending. According to Rustono (1999, p. 41) directive speech acts are speech acts intended by the speaker so that the speech partner performs the actions mentioned in the speech. Coercive, inviting, requesting, ordering, charging, pressing, pleading, suggesting, ordering, giving cues, and challenging speech are included in the types of directive speech acts. Not much different from the previous one, according to Koizumi (1993, p. 337), the directive is as follows:

話し手が、聞き手にある行為をさせようと試みる. （命令、依頼、質問など）

Hanashite ka, kikite ni aru koui wo saseyou to kokoromiru. (meirrei, irai,shittsumon nado)

The speaker tries to get the speech partner to do an action (orders, requests, questions, and so on)

Examples of the directive act:

ドアを閉めるように（命令する）

Doa o shimeru youni (meirei suru)

Close the door (give orders) (Koizumi, 1993, p. 337)

The speech is a directive speech act because the speaker has the intention of making the speech partner take action ordered. The speech is spoken by the speakers solely so that the speech partner closes the door. There is an action to call this speech a directive speech that must be taken by the speech partner after hearing the speech. 


\section{Commissive}

In Japanese, commissive is called genmeiteki (言明的). The commissive speech act is a form of speech used to express a certain promise or offer. Commissive forms of speech are promising, swearing, and offering. According to Rustono (1999, p. 42) commissive speech acts are speech acts that bind the speaker to carry out what is stated in the speech. Promising, swearing, threatening, declaring commitment, and making vows are utterances that are classified as commissive acts. Unlike before, according to Koizumi (1993, p. 337), commissive is as follows:

話し手が将来における行為の実行を言明する。（約 束、警告、忠告、宣誓、など)

Hanashite ga shourai ni okeru koui no jukkou wo genmeisuru. (yakusoku,keikoku, chuukoku, sensei, nado)

The speaker states the embodiment of the action to be carried out in the future (promise, give warning, give advice, oath, and so on)

Examples of commissive in Japanese:

あすまでに仕事をしておきます（と約束する）

Asu made ni shigoto wo shite okimasu (to yakusoku suru) 337)

I'll work until tomorrow (promise). (Koizumi, 1993, p.

The speech is a commissive speech act because it binds the speaker to do something in the future. This speech is a promised commissive speech because the speaker promises to work until tomorrow.

\section{Expressive}

In Japanese, expressive speech is called hyoushutsuteki (表出的). Expressive speech act is a form of speech that functions to express or show a speaker's psychological attitude towards certain circumstances. Expressive speech forms are thanking, congratulating, pardoning, blaming, praising, and condoling. According to Rustono (1999, p. 41) expressive speech acts are speech acts intended by the speaker so that the utterance is interpreted as an evaluation of what is mentioned in the speech. Speeches of praise, thanking, criticizing, complaining, blaming, congratulating, and flattering are included in the types of expressive speech acts. In contrast to the previous theory, Koizumi (Koizumi, 1993 ) states that expressiveness is as follows.

話し手の感情を表明する。（感謝、遺憾、歓迎、祝 福、など）

Hanashite no kanjou wo hyoumeisuru. (kansha, ikan, kangei, shukufuku, nado)

Express the speaker's feelings (give thanks, regret, welcome, convey blessings, and so on).

Expressive examples in Japanese:

贈り物をありがとうございます（と感謝する）

Okurimono wo arigatou gozaimasu (to kansha suru) $337)$
The speech is an expressive speech act because the speaker expresses his gratitude to the speech partner for the gift that the speech partner has given to the speaker. This speech is interpreted as a sense of respect for the speech partner's actions who gives the gift.

\section{E. Declaration}

In Japanese, declarative is called sengenteki (宣言的). The declarative speech act is a form of utterance that connects the content of speech with reality. The declarative speech forms are resigning, dismissing, christening, naming, appointing, excommunicating, and sentencing. According to Rustono (1999, pp. 42-43), declarative speech act is speech act intended by the speaker to create new things (status, circumstances, etc.). Speeches to ratifying, deciding, canceling, prohibiting, permitting, granting, lifting, classifying, forgiving, and forgiving are included in declarative speech acts. Unlike before, according to Koizumi (1993: 337), the declarative is as follows.

ある慣習にもとづき、事態に直接变化を及ぼす発 言。（布告、命名、宣言、など）

Aru kanshuu ni motozuki, jitai ni chokusetsu henka wo oyobosu hatsugen.(fukoku, meimei, sengen, nado).

Statements use direct change to or in a situation, based on a habit (statement, name, declaration, etc).

Declarative example in Japanese:

ここに開会を宣言します。

Koko ni kaikai wo sengen shimasu.

I hereby announce that the meeting has been opened. (Koizumi, 1993, p. 337)

The speech is a declarative speech act because the speaker decides something, and then something changes in conditions and situations. This speech is a declarative speech act because the speaker announces that the meeting has been opened.

From the description above, it can be seen that pragmatic studies on speech acts are very interesting to do, especially illocutionary speech acts. In this study, illocutionary speech acts were investigated in the learning process of students of the Mandarin Language Department, Faculty of Cultural Studies, University of Sumatera Utara. In addition to studying Mandarin, students also learn Japanese as a foreign language course. The background of basic skills in Indonesian, Mandarin, or maybe English will undoubtedly make the speech acts used in the class vary.

Japanese language courses at the Mandarin Language Department, Faculty of Cultural Studies, University of Sumatera Utara are the research object. The results of previous researchers' brief observations found that many utterances were used, such as illocutionary speech acts in the form, function, and narrative strategy. Thus, the authors are expected to embody this in real life and reveal students' utterances.

Research on speech act analysis using a pragmatic approach has been conducted by several previous researchers, including Hidlir (2013) Nurwahida (2014), Mughofar (2018), Hajijah (2017), and Rasa (2019). Hidlir (2013) examines supervisors' speech acts in academic supervision activities for high school teachers in the East 
Lombok district in 2012/2013. The data found in the study namely 1) types of speech acts in academic supervision activities including (1) direct speech acts, (2) indirect speech acts, (3) literal, (4) non-literal, (5) direct literal, (6) indirect literal, (7) indirect literal, and (8) indirect, not literal. Of the eight speech acts, the most dominant ones were direct speech acts and literal speech acts.

Furthermore, Nurwahidah (2014) analyzes students' speech acts of SMP Negeri 19 Bulukumba in the learning process. The data obtained in this study suggest several forms of speech acts used by students of SMP Negeri 19 Bulukumba in the learning process, especially in the discussion. The grouping of speech act forms includes; speech act based on their nature, function, and continuity. Based on this research, there are similarities in postulates, namely, limited understanding of speech acts' theories. Other research also conducted by Mughofar (2018), Hajijah (2017), and Rasa (2019), these studies are research in Indonesian language classes, where illocutionary speech acts are examined in the Foreign Language class (Japanese)

Research on illocutionary speech acts by students of the Mandarin Language Department, Faculty of Cultural Sciences, University of Sumatera Utara is a development of previous research. However, previous researchers' research object is different from the current research object. Therefore, if the research object is different and the theory used to dissect the information is also different in conducting research, it will produce different findings.

Based on many descriptions above, this research's objectives are (1) to analyze the form of illocutionary speech acts in Japanese for students of the Mandarin Language Department, Faculty of Cultural Sciences, the University of Sumatera Utara in the Japanese language learning process. (2) to explain the purpose of illocutionary speech acts in student interactions

\section{METHOD}

This research is qualitative with descriptive method, and is implemented by carefully recording all linguistic phenomena following the original in order to provide the data on speakers' language. This research does not determine the research based on research variables, but the overall social situation studied by Sugiyono (2016, p. 285) includes aspects of the place, actor, and activity that interact synergistically. The social situation referred to in this study is the illocutionary speech act (activity) of the student (actor) in the Mandarin Study Program in the learning process (place). This research focuses on realizing students' speech acts in the lecture process or Japanese language learning, especially illocutionary speech acts.

In this research, the data sources were 40 students of the $4^{\text {th }}$ semester, the Mandarin Language Department in the Japanese language lecture process. The data were utterances or conversations in the lecture process in class, especially in the discussion. Data were collected through field research observations. Every speech act in Japanese in the classroom was recorded using note-taking technique, then continued at the data analysis stage.

The data analysis technique used Miles, Huberman \& Saldana (2014) consisting of data condensation, presentation, and the conclusion. In the condensation stage, data were selected and selected according to their needs in solving research problems. The illocutionary speech acts analyzed were only the spoken in Japanese. Then the data were displayed in the form of example sentences which were transcribed and analyzed for their forms. From the description and analysis, the conclusions were drawn that answer the research problem.

\section{RESULTS AND DISCUSSION}

This research shows that there are several forms of illocutionary speech acts by 4th semester Mandarin department students in learning Japanese at the University of Sumatera Utara. The forms of illocutionary speech acts include directive, expressive, and declarative speech acts.

The objectives of the speech acts used in the classroom include ordering, asking, inviting, praising, and forbidding. The following explains the data regarding to the speech acts found in this research.

\section{A. Form and Objectives of the Directives' Speech Acts}

In this research, directive illocutionary speech acts are found that aim to instruct, ask, and invite. The form of speech data, which is included in the types of directive speech acts in the interaction of Japanese language learning for Mandarin Language Department, Faculty of Cultural Studies, University of Sumatera Utara can be explained in the following section.

\section{Directive Acts to order}

Directive acts to order are utterances included in directive speech acts. Order speech is speech that expresses action, and this can be shown in the speech below.

(1) Data 1

Speech: ちょっと、あついですね。エアコンは

Chotto, atsui desu ne. Eakon wa

It's a bit hot. The air conditioner

\section{Analysis:}

Data one consists of two sentences. The first sentence is chotto Atsui desu ne. In this sentence, the word chotto means a little or a little while, and the word atsui desu ne means hot. In the second sentence is eakon wa, where the word eakon means air conditioner (AC).

The lecturer spoke both sentences to students in a crowded and stuffy classroom situation. Lecturers who have just entered the classroom and felt the class's condition was crowded and stuffy said the above sentence while waving their hands to their faces. The lecturer expressed the speech with an expression of stifling heat and discomfort in the classroom conditions while looking at the air conditioner.

Chotto atsui desu ne. Eakon wa means that the lecturer informs that if the class conditionis hot, the instructor indirectly orders them to turn on the air conditioner (AC). This can be seen from the student's response, who immediately moves to take the $\mathrm{AC}$ remote and turns it on.

The lecturer instructs students to turn on the air conditioner so that the classroom's air temperature is cool and comfortable for studying.

\section{Directive Acts to Request}


This is a speech act to influence the speech partner to take action asking, whether it is in an act or just a speech. The speech that shows asking is in the following speech:

(2) Data 2

Speech: 私の本はどれですか。ああ。。それは私のです Watashi no hon wa dore desuka. aa.. sore wa watashi no desu

Which is my book? Well .. that's my book.

Analysis:

Data 2 consists of two sentences. In the first sentence watashi no hon wa dore desuka, the word watashi no hon means my book. The word dore desu ka means which one. The second sentence is sore wa watashi no desu which means it is mine.

The lecturer expressed this sentence to the students in the class when they were leaving the classroom to end the lecture. The lecturer asked one of the students for the book he gave at the beginning of the lesson and pointed to one book, which was his book.

Watashi no hon wa dore desuka. aa. sore wa watashi no desu is pronounced with asking and pointing at the book on the student table. Students who hear the speech respond by looking at the book, taking it, and bringing it to the lecturer.

The purpose of using the illocutionary speech act is that the lecturer asks the student who holds the teaching book to hand it over to the front of the class.

(3) Data 3

Speech: 先生、字が見えません。

Sensei, ji ga miemasen

Sir, I can't see the letters.

In sentence Sensei, ji ga miemasen, the word ji means 'letter,' and miemasen means 'unreadable.'

The sentence was expressed by one of the students to the lecturer (sensei) who was explaining the topic of the lecture while writing it on the blackboard.

Students use the utterance "Sensei, ji ga miemasen" to make sensei to clarify the writing on the board by rewriting it in a larger size. This can be seen from Sensei's response which immediately erases the writing and rewrites it with a size larger than the previous one.

The purpose of using illocutionary speech acts is that students ask sensei to write down the topic of percussion, which is written on the board with a larger writing size so that all students in the class can read it.

\section{Directive Acts to engage}

Directive Acts to engage speech that influences the speech partner to take action. The utterance that shows the speech is as follows.

(4) Data 4

Speech: はい、皆さん、質問はありますか。じ や。ここまで終わります。また来週。

Hai, minasan, shitsumon wa arimasu ka. Jya. Kokomade owarimasu. Mata raishuu

All right, any questions? Then we'll end here. See you next week

\section{Analysis:}

The speech has three sentences. The first sentence is hi, minasan, shitsumon wa arimasu $k a$, where the word shitsumon means a question, and the word arimasu means whether there is any-the particle $k a$ functions as an interrogative sentence. The second sentence is Jya. Kokomade owarimasu, where the word jya has a meaning then, the word koko made has the meaning here, and the word owarimasu means ending. The last sentence is mata raishuu which has meaning until next week.

The lecturer spoke this speech to students at the end of the lecture after the lecturer explained all lecture topics. The utterances "Hai, Minasan, shitsumon wa arimasu ka. Jya. Kokomade owarimasu. Mata raishuu" were expressed by the lecturer to invite students to end lectures, and hurry out of the classroom. This can be seen from the students' response, who clear the equipment and put the books in their bags when the lecturer say these. When the lecturer left the room after the utterances were spoken, some students also followed the lecturer from behind to go out of the classroom.

The purpose of using illocutionary speech acts is that the lecturer invites students to finish lecture and immediately leaves the classroom.

\section{B. Form and Objectives of Expressive Speech Act}

This research found expressive illocutionary speech acts of praise. As for what is included in the types of expressive speech acts in Japanese language learning interaction of Mandarin Language Department students at the University of Sumatera Utara can be explained below.

\section{Expressive Actions to Praise}

Expressive speech act of praise is speech acts carried out with the intention that the speech is interpreted as an evaluation of what is mentioned in the speech, which contains praise. Praise speech is a speech that is used as an expression of admiration for something beautiful, good, brave, and so on. Expressive speech acts of praise can be shown in the speech below:

(5) Data 5

Speech: うあ。。将来、あなたは先生になります。 Ua... shourai, anata wa sensei ini narimasu

Whoa. In the future, you will become a lecturer.

Analysis:

In the sentence shourai, anata wa sensei is narimasu, the word shourai means future, the word anata means you, and the word narimasu means to be.

This sentence was expressed by a student to another student when the student who was the speech partner came forward to write the sentence ordered by the lecturer.

Students praise their friends who can write sentences correctly on the blackboard using speech shourai anata wa sensei is narimasu to increase enthusiasm in learning. This can be seen from the responses of students who smile happily when uttered.

\section{Form and Objectives of Declarative Speech acts}

In this research, we found illocutionary speech acts of the declaration to prohibit. 


\section{Speech Acts Forbid}

Prohibiting speech act is a speech acts performed by speakers to create new things (status, circumstances, etc.) by using a speech containing prohibitions. Prohibiting speech is a speech done to order not to do what is prohibited.

(6) Data 6

Speech: そこの人、何をしていますか。

Soko no. hito, nani o shite imasu ka.

You over there, what are you doing.

\section{Analysis:}

In the sentence Mina san, nani o shite imasu ka, the word nani means what, and the word shite imasu ka means to do.

These speeches were spoken by the lecturer to the students. While the instructor was explaining, several students were chatting behind him. Therefore, the lecturer admonished the students with these words. Students who listened to the utterances did not answer questions but only stoped the chat, straighten their eyes forward and remained silent.

The speech used by the lecturer, "nani o shite imasu ka" means that students do not chat while the lecturer is explaining. The purpose of using illocutionary speech acts is that the pursuer prohibits the chatting activities carried out by students when the lecturer explains the topic or material of the lecture.

\section{CONCLUSIONS}

This research concludes that there is a form of illocutionary speech acts in Japanese language learning for students of the Mandarin Language Department, Faculty of Cultural Sciences, University of Sumatera Utara. The forms of illocutionary speech acts include directive, expressive, and declarative speech acts.

Furthermore, the purpose of speech acts used in class, among others, in directive speech acts is to order, ask, invite (engage). In expressive illocutionary speech acts, it is praising, and in declarative illocutionary speech acts, it is prohibiting. The speech acts in Japanese also seem to be influenced by the limited abilities and vocabulary that students learn.

\section{ACKNOWLEDGMENT}

This research is internal research of Harapan Medan University in 2020 and is funded by the Institute for Research and Service (LPPM), Universitas Harapan Medan. We also express our great appreciation for the Mandarin
Language Department, Faculty of Cultural Sciences, the University of Sumatera Utara, which has collaborated to implement this research.

\section{REFERENCES}

Austin, J. L. (1962). How to do things with words. Oxford University Press.

Grice, H. P. (2004). Logic and conversation. University College.

Hajija, S., Suryadi, S., \& Djunaidi, B. (2017). Tindak tutur ilokusi guru bahasa Indonesia pada proses pembelajaran di kelas XI IPA 1 SMAN 9 kota Bengkulu. Jurnal Ilmiah KORPUS, l(2), 210-217. https://doi.org/10.33369/jik.vli2.4122

Hidlir, L. M., Suandi, I. N., \& Putrayasa, I. B. (2013). TINDAK TUTUR PENGAWAS DALAM KEGIATAN SUPERVISI AKADEMIK PADA GURU SMA DI KABUPATEN LOMBOK TIMUR TAHUN 2012/2013. Jurnal Pendidikan Dan Pembelajaran Bahasa Idonesia, 2(1). https://ejournalpasca.undiksha.ac.id/index.php/jurnal bahasa/article/view/8 81

Koizumi, T. (1993). Nihongo kyoushi no tame no gengogaku nyuumon. Taishukan Shoten.

Koizumi, T. (2001). Nyuumon goyouron kenkyuu : riron to ouyou. Kenkyuusha.

Leech, G. (1993). The principles of pragmatics. Terjemahan (terjemahan) (M. D. D. Oka \& S. Setyapranata (eds.)). Universitas Indonesia.

Miles, M. B., Huberman, A. M., \& Saldana, J. (2014). Qualitative data analysis. Sage Publications.

Mughofar, M. N. K. (2018). Tindak tutur direktif dalam Family Development Session (FDS) (kajian sosiopragmatik). JURNAL PESONA, 4(2), 10 https://doi.org/10.26638/jp.703.2080

Nirmala, V. (2015). Tindak tutur ilokusi pada iklan komersial $\begin{array}{lll}\text { sumatera } & \text { ekspres. } & \text { KANDAI, }\end{array}$ https://doi.org/https://doi.org/10.26499/jk.v11i2.222

Nurwahidah. (2014). Analisis tindak tutur siswa SMP Negeri 19 Bulukumba dalam proses pembelajaran (suatu tinjauan pragmatik). Universitas Negeri Makassar.

Rasa, M. P. D. B., Andayani, A., \& Ulya, C. (2019). Analisis tindak tutur ilokusi dalam dialog naskah drama Peace karya putu wijaya dan relevansinya dengan materi ajar sastra di Sekolah Menengah Atas. Basastra: Jurnal Bahasa, Sastra, Dan Pengajarannya, $7(1), \quad 27$. https://doi.org/10.20961/basastra.v7i1.35499

Rustono. (1999). Pokok-pokok pragmatik. IKIP Semarang Press.

Searle, J. R. (1983). Speech acts, an essay in the philosophy of language. University Press.

Sugiyono. (2016). Metode penelitian kuantitaif: Kualitatif dan $R \&$ $B$. Alfabeta.

Yule, G. (2006). Pragmatics (I. F. Wahyuni (ed.); Terjemahan) Pustaka Pelajar. 